\title{
Adult Type Granulosa Cell Tumor
}

National Cancer Institute

\section{Source}

National Cancer Institute. Adult Type Granulosa Cell Tumor. NCI Thesaurus. Code C66750.

A granulosa cell tumor occurring in the ovary and rarely in the testis. It is composed of granulosa cells in an often fibrothecomatous stroma. The neoplastic cells may form various patterns including the microfollicular, which is characterized by the presence of Call-Exner bodies, macrofollicular, insular, trabecular, and diffuse pattern. In females, it affects middle aged to post-menopausal women. Signs and symptoms include abdominal mass, hemoperitoneum, and ascites. Estrogenic and rarely androgenic manifestations may be present. The vast majority of cases present as stage I tumors; however, all tumors have a potential for aggressive clinical course. In males, it is reported in the age range of $16-76$ years and the average age at presentation is 44 years. A minority of patients have gynecomastia. Metastases have been reported in a minority of patients. 